\title{
Geological Control upon Groundwater Flow and Major Ion Chemistry with Influence on Basin Management in a Coastal Aquifer, South Australia
}

\author{
Nara Somaratne, Jacqueline Frizenschaf \\ South Australian Water Corporation, 250 Victoria Square, Adelaide, Australia \\ Email: "nara.somaratne@sawater.com.au
}

Received August 7, 2013; revised September 11, 2013; accepted October 6, 2013

Copyright (C) 2013 Nara Somaratne, Jacqueline Frizenschaf. This is an open access article distributed under the Creative Commons Attribution License, which permits unrestricted use, distribution, and reproduction in any medium, provided the original work is properly cited.

\begin{abstract}
Estimation of natural recharge and potential for seawater intrusion are critical considerations for management of coastal freshwater aquifers. We show hydrochemical signatures of groundwater to identify the influence of geological control on chemical processes in a coastal groundwater system. We used dominant hydrochemical facies, salinity and magnesium ions to determine two main groundwater flow paths with different origins and ages. Mixing of groundwater with different origins and ages results in unreliable recharge estimates using chlorofluorocarbon (CFC) and chloride mass balance (CMB) methods, thus limiting available methods for recharge assessment. Interpretation of hydrochemical data suggests that calcium carbonate dissolution, ion exchange processes and mixing with sea aerosol in coastal zones are the main influencing factors on groundwater chemistry. Restricted groundwater flows due to occurrence of a basement high at the southern side of the basin boundary influence the distance to the toe of the saline wedge. Thus, knowledge of geological control over groundwater systems forms an important part of characterising basins and contributes toward effective management of groundwater resources.
\end{abstract}

Keywords: Hydrochemistry; Groundwater Mixing; Groundwater Management; Recharge

\section{Introduction}

Spatial distribution of groundwater chemistry is primarily influenced by mineralogical composition of sediments in contact with groundwater [1]. The nature and distribution of aquifers and aquitards in a geologic system are controlled by the lithology, stratigraphy and structure of geologic formations. The main geological controls are the stratigraphy and structural features such as cleavages, fractures, faults, and solution features which are the geometrical properties of the geologic systems. The influence of geological control changes natural water chemistry and therefore knowledge of main hydrochemical processes that control groundwater chemistry is a prerequisite for effective basin management [2]. Several studies examined the influence of geological controls: the presence of faults [3,4]; geology and structure of bedrock $[5,6]$; fracture control [7] which influences groundwater flow and water chemistry; and hydrogeological study of

${ }^{*}$ Corresponding author. groundwater flow diversion caused by anticlinal structures [8].

Among geological controls, the presence of faults and their influence on flow paths and water chemistry are widely reported and these are known to be effective flow barriers [3]. Green et al. [4] reported flows across regional scale faults and found that groundwater flow either enhanced or inhibited, depended on orientation of fractures with respect to the cross fault hydraulic gradient. Bensel et al. [9] and Meeder [10] related the impact of faults on near surface processes to surface features such as vegetation patterns and drainage networks; and thus, faults can have great influence on transport processes in the sub-surface and are important in water management.

Eaton et al. [7] noted that there are few studies on the hydrogeology of sedimentary rock aquitards, although they are important controls in regional ground water flow systems. Cherry et al. [11] highlighted that determination of aquitard integrity is an important aspect of groundwater management because it influences water quality. Thus, 
the presence or absence of an aquitard, which is not necessarily a confining unit, can have a significant impact on basin water quality. We examined effects of basement rock outcrop and discontinuity of the clay aquitard on groundwater salinity, water chemistry, influence on recharge estimation methods and extent of the saline wedge in a coastal aquifer in South Australia.

\section{Study Area}

The Uley South basin is located in the Southern Eyre Peninsula in South Australia (Figure 1). Average annual rainfall and pan evaporation is $550 \mathrm{~mm}$ and $1550 \mathrm{~mm}$, respectively. The basin is used for town water supply with current allocation of about $6.8 \times 10^{6} \mathrm{~m}^{3}$ per year. The geology and hydrogeology of the basin is characterised based on: Segnit [12], Johns [13], Morton and Steel [14], Wilson [15], and Shepherd [16]. These works include development of a geological model from borehole information, geological surface mapping, delineation of saturated limestone boundaries and pumping tests with attention focussed on Uley Wanilla, Uley East and Uley South groundwater lenses.

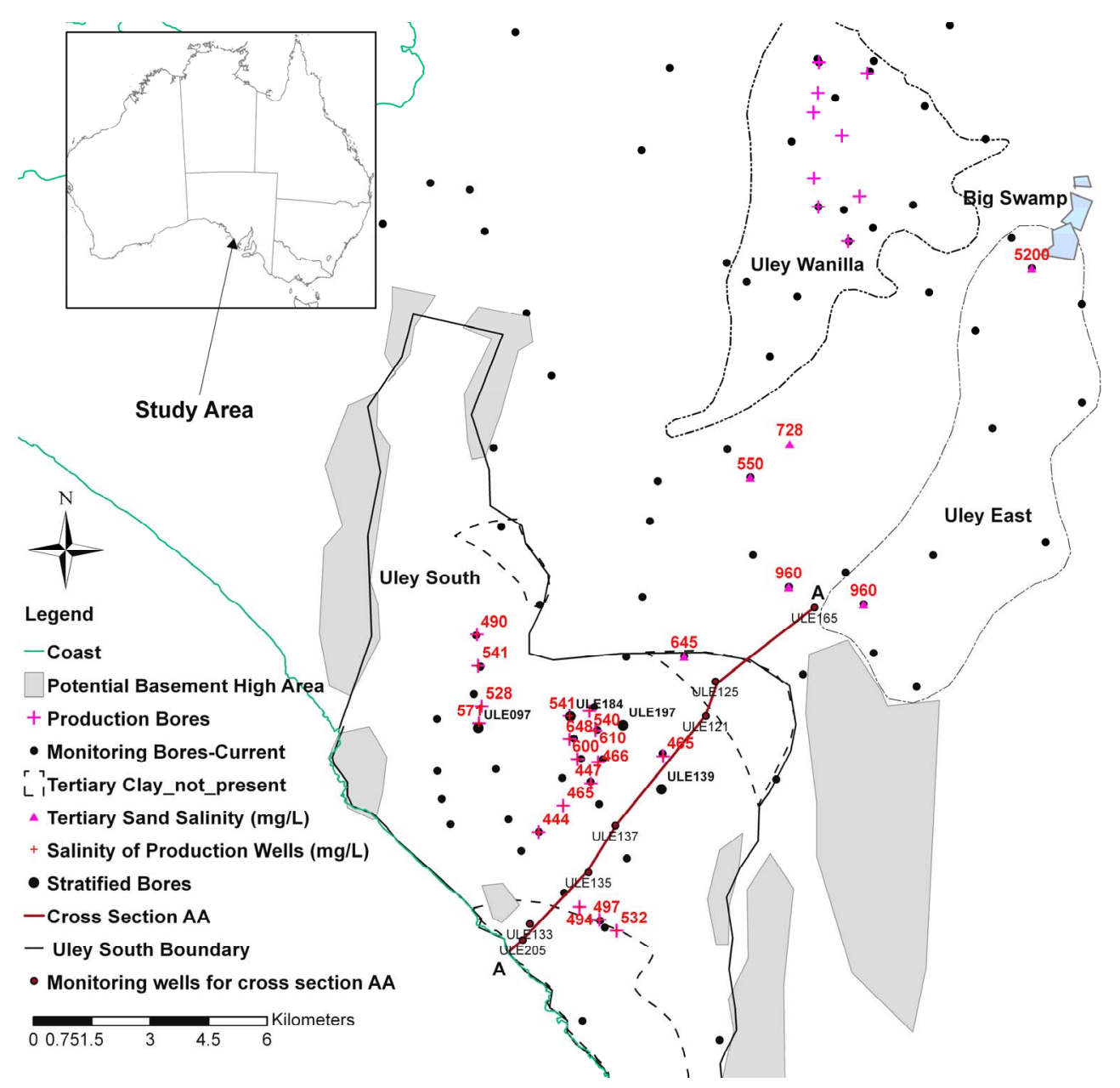

Figure 1. Location of the study area.
The aquifer system in Uley South is comprised of Quaternary Bridgewater Formation limestone (QL aquifer), beneath this is the Upper Tertiary Clay (Uley Formation) unit with thickness of $5-25 \mathrm{~m}$, which forms an aquitard between the Tertiary Sand (TS) of Wanilla Formation and the Quaternary aquifer systems [14]. Recent studies $[17,18]$ show that there is a hydraulic connection between the Uley South unconfined QL aquifer and the Uley Wanilla and Big Swamp areas through the TS aquifer (Figures 1 and 2). The basin is topographically closed and the low-lying central portion contains numerous sinkholes. Runoff is highly ephemeral, occurs only after moderate to high intensity rainfall and persists only tens to hundreds of meters before entering a sinkhole [17, $19,20]$. Surface drainage is poorly developed as is typical of semi-arid karstic terrains that support only thin soils combined to produce scant vegetation. The groundwater flow direction in Uley South is from north-east to southwest.

An important surface feature is the Big Swamp (Figure 1) with an underlying Tertiary Clay with the primary mechanism of discharge through evaporation. In wetter 


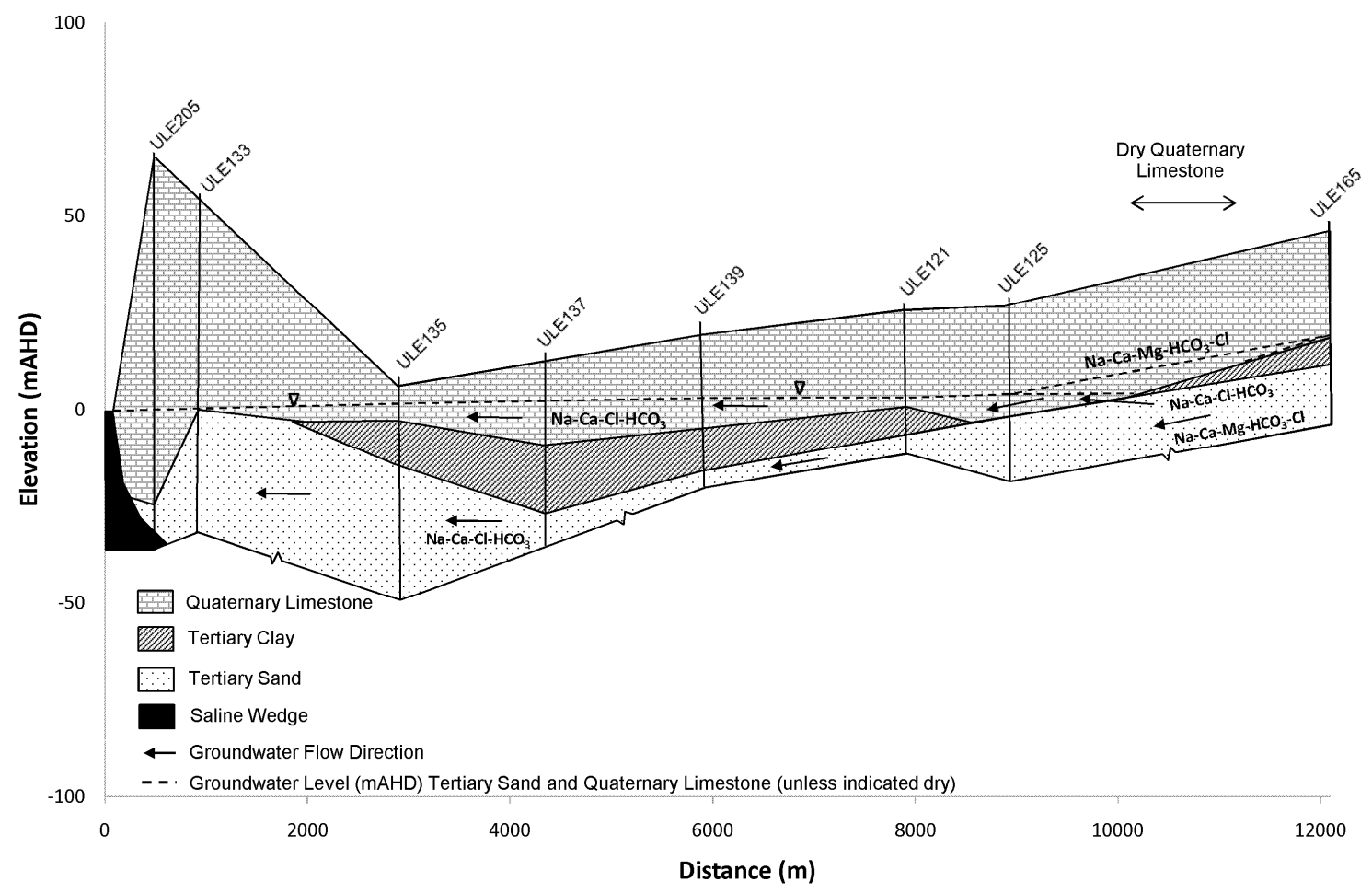

Figure 2. Cross section AA from the coast in the Uley South basin to Uley East basin's western edge.

years, Big Swamp overflows and infiltrates into the Quaternary Limestone unconfined aquifer and leaks into the TS aquifer raising salinity up to $5200 \mathrm{mg} / \mathrm{L}$ near Big Swamp.

\section{Results and Discussion}

The influence of geological control is divided into three sections: influence on QL aquifer salinity, hydrochemistry of QL groundwater, and the effect of extension of the saline wedge in TS aquifer. These are important factors in managing the Uley South basin.

\subsection{Influence on Salinity}

In Uley South, the occurrence of basement high at the basin boundary and discontinuity of aquitards and solution features constitute the most important controls upon salinity and water chemistry. Salinity measurements taken from the town water supply (TWS) wells indicate higher salinity in the north-central portion than elsewhere in the basin (Figure 1). Salinity distribution in the basin is influenced by two main geological controls: the occurrence of basement high in the southern half of the basin, and the area of Tertiary Clay absence in the central part (Figures 1 and 2).

Harrington et al. [17] and Somaratne [18] show that the high-salinity plume of groundwater in the TS aquifer originates from the Big Swamp area as a result of downward leakage of Big Swamp's surface water through the clay aquitard. As the plume moves down gradient along its main flow path, the western edge of the Uley East basin, it is diluted from $5200 \mathrm{mg} / \mathrm{L}$ salinity at Big Swamp to $960 \mathrm{mg} / \mathrm{L}$ at the southern boundary of the Uley East basin. The area where aquitard is absent in Uley South, the TS aquifer receives direct recharge, resulting in further dilution of salinity to $645 \mathrm{mg} / \mathrm{L}$ (Figure 1). As a result, pronounced salinity stratification is found in QL aquifer monitoring well ULE197, down-gradient to the Tertiary Clay absence area (Figure 3(a)). In the ULE197 well, salinity of the QL base is identical to that in TS aquifer monitoring well ULE109, located at the same site. Harrington et al. [17] indicated that residence time in Big Swamp and Uley Wanilla groundwater age is $>45$ years. Mixing of old waters originating from Uley Wanilla and Big Swamp with younger water $(<20$ years) in Uley South has important ramifications on applicable recharge estimation methods. When mixing occurs of different groundwater systems with different ages and different chlorides concentrations, this results in unreliable recharge estimates using chlorofluorocarbon $[21,22]$ and chloride mass balance methods $[23,24]$, thus limiting the methods available for recharge assessment.

In contrast, the southern half of the QL aquifer has no link to the Big Swamp area through either QL or TS aquifers due to occurrence of the basement high at the Uley South boundary (Figure 1). Therefore, QL water in the southern part of Uley South is primarily derived from direct rainfall recharge within Uley South. ULE139 is a 
QL aquifer monitoring well, which shows no evidence of salinity stratification (Figure 3(b)).

\subsection{Influence on Hydrochemical Signatures}

The combination of aquifer heterogeneity, low hydraulic gradient, recharge through solution features in addition to diffuse recharge, mixing with different water types and modification along flow paths results in Uley South being hydrochemically complex. Hydrochemistry was assessed principally by major ion chemistry within the Uley Wanilla, Uley East and Uley South lenses, and how these are related to evolution of hydrochemical processes in the Uley South basin.

Groundwater can be classified into "water types" on the basis of the absolute and relative abundance of major ions [25]. However, due to the predominance of $\mathrm{Na}$ and $\mathrm{Cl}$ ions in both QL and TS aquifers, the major ion differences present are inconclusive in distinguishing between QL and TS waters. For all QL and TS groundwaters, Ordens et al. [20] has shown that $\mathrm{Cl} / \mathrm{Br}$ in both rainfall and groundwater samples are close to the $\mathrm{Cl} / \mathrm{Br}$ ratio of seawater indicating groundwater chloride are marine derived implying that both QL and TS waters may have similar chemical histories.

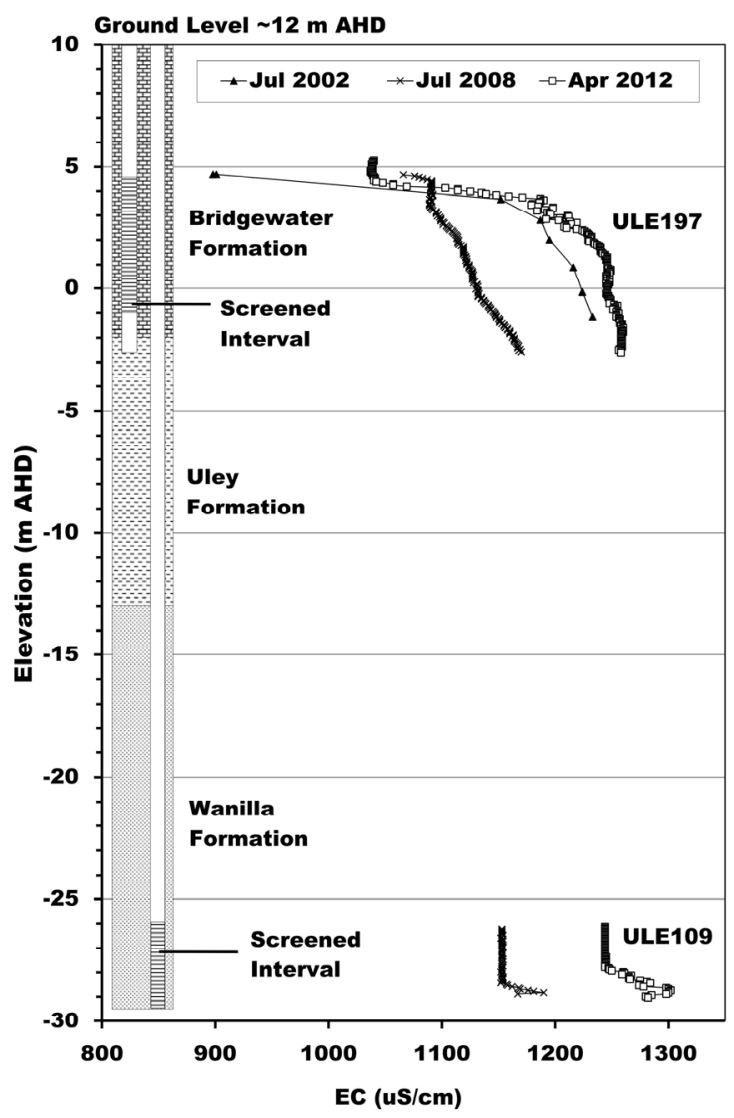

(a)
Discrimination based on relative major ion abundance is more successful where recharging freshwater is of continental $\left(\mathrm{Ca}-\mathrm{HCO}_{3}\right.$ type) rather than marine ( $\mathrm{Na}-\mathrm{Cl}$ type) origin as in Uley South. QL and TS groundwater are analysed for $\mathrm{pH}$, electrical conductivity, anions $\left(\mathrm{HCO}_{3}^{-}\right.$, $\left.\mathrm{SO}_{4}^{2-}, \mathrm{Cl}^{-}\right)$and cations $\left(\mathrm{Ca}^{2+}, \mathrm{Mg}^{2+}, \mathrm{Na}^{+}, \mathrm{K}^{+}\right)$. Although the majority of water has no dominant ion composition, Uley Wanilla water contains distinctively high Mg ions (Figure 4) as observed by Harrington et al. [17]. High chloride in TS waters is derived from the Big Swamp area and the $\mathrm{Na}-\mathrm{Cl}$ type water is diluted towards $\mathrm{Na}-\mathrm{Cl}-\mathrm{HCO}_{3}$ waters at Uley South. This represents either waters that have chemically evolved along flow paths or that result from mixing between $\mathrm{Na}-\mathrm{HCO}_{3}$ waters and $\mathrm{Na}-\mathrm{Cl}$ waters.

Classification of groundwater into water types on the basis of major ion composition and other selected characteristics provides a framework for interpretation of groundwater pathways [26]. Eighty-five groundwater samples were used for QL aquifer. This includes the data of Evans [19] and town water supply wells' water quality data. For the TS aquifer, twenty-seven water samples were taken from Evans [19].

Hydrochemical examination shows that carbonate dis-

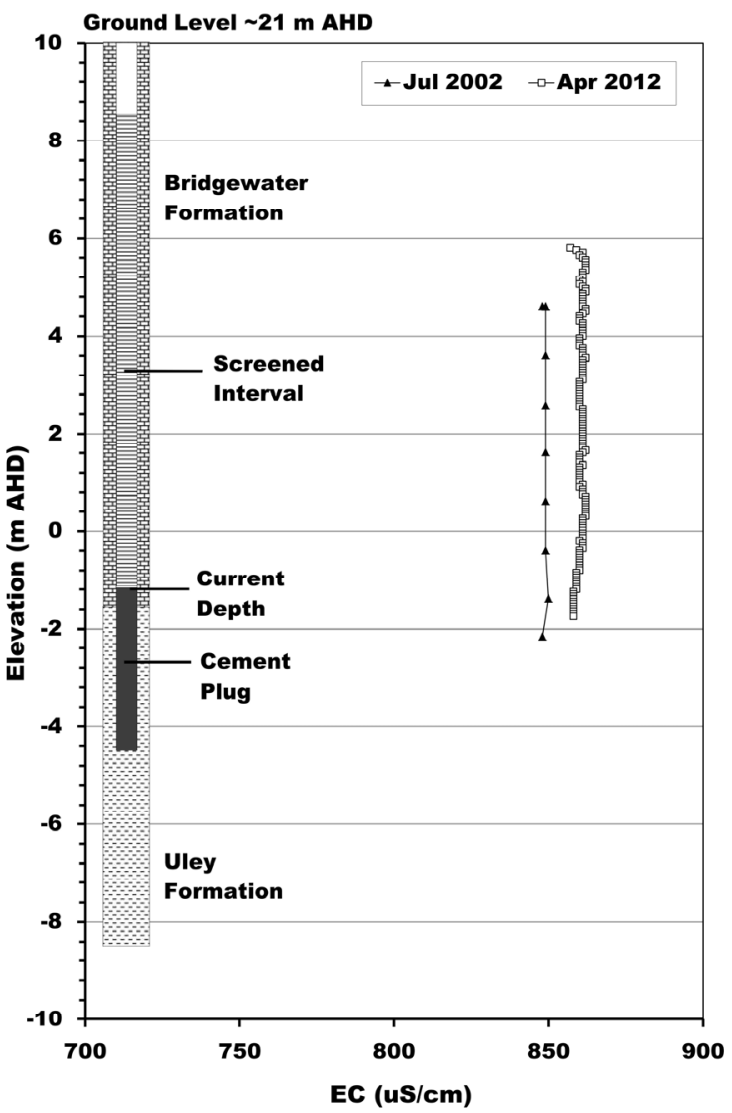

(b)

Figure 3. Salinity stratification of QL groundwater in the central part of the basin. (a) ULE109 and ULE197; (b) ULE139. 


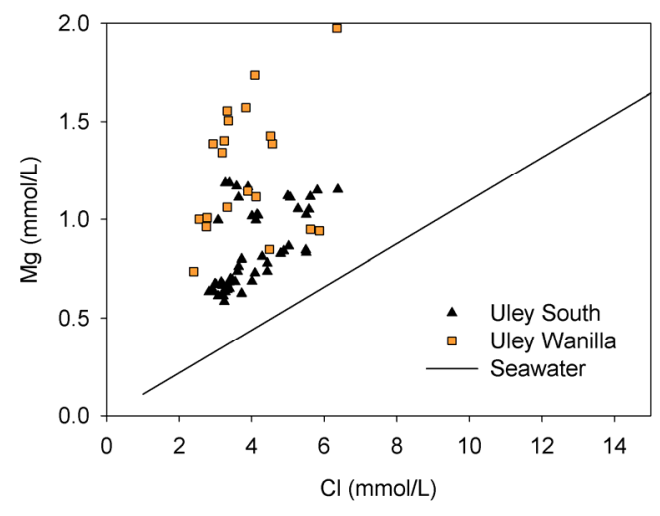

Figure 4. Cl vs Mg in Uley Wanilla and Uley South lenses.

solution and ion exchange are the two dominant chemical processes active in the QL aquifer. Water types are categorised into four types of groundwater, which represents a chemical evolution from $\mathrm{Na}-\mathrm{Mg}-\mathrm{Cl}-\mathrm{HCO}_{3}$ groundwater at Uley Wanilla lens to end member $\mathrm{Na}-\mathrm{Cl}$ groundwater at Big Swamp (Figure 5).

\subsubsection{Na-Cl or Na-Ca-Cl (1)}

In the absence of evaporites, this type of water occurs in the Big Swamp due to enrichment of $\mathrm{Na}$ and $\mathrm{Cl}$ ions though evaporation. The end member of this water type is $\mathrm{Na}-\mathrm{Ca}-\mathrm{Cl}-\mathrm{HCO}_{3}$ or $\mathrm{Na}-\mathrm{Ca}-\mathrm{HCO}_{3}-\mathrm{Cl}$ in the north-central part of Uley South basin, where salinity of town water supply wells are about $650 \mathrm{mg} / \mathrm{L}$; about $100 \mathrm{mg} / \mathrm{L}$ higher than elsewhere in the QL aquifer.

\subsubsection{Na-Mg-Ca-Cl-HCO ${ }_{3} / \mathrm{Na}-\mathrm{Ca}-\mathrm{Mg}-\mathrm{HCO}_{3}-\mathrm{Cl}$ (2)}

$\mathrm{Na}-\mathrm{Mg}-\mathrm{Ca}$ or $\mathrm{Na}-\mathrm{Ca}-\mathrm{Mg}$ water indicates that dissolution of dolomite (or dolomitic limestone) is taking place in the catchment area. In Quaternary Limestone, this type of water occurs in the Uley Wanilla basin (Figure 6). In the TS aquifer, this type of water occurs either within the Uley Wanila basin or directly down-gradient in the flow direction, indicating direct leakage (interconnection between two aquifers) from QL to TS aquifer. This type of water in the Uley South QL aquifer is found only in production bores directly down gradient to Tertiary Clay absence area as a result of QL aquifer receiving TS waters. Apart from production wells directly down gradient, none of the monitoring wells nor any other town water supply wells contain this type of water.

\subsubsection{Ca-Na-HCO $3-\mathrm{Cl} / \mathrm{Ca}-\mathrm{Na}-\mathrm{Mg}-\mathrm{HCO}_{3}-\mathrm{Cl}$ (3)}

This is the typical water type found in limestone aquifers. The $\mathrm{Ca}-\mathrm{Na}-\mathrm{HCO}_{3}-\mathrm{Cl}$ water type represents recently recharged water with an abundance of dissolved $\mathrm{CO}_{2}$; thus calcite dissolution is taking place. This water type occurs in the southern part of the central basin where there is no TS water mixing with Uley South QL aquifer water. Uley South basin being a karstic limestone aquifer, sink-

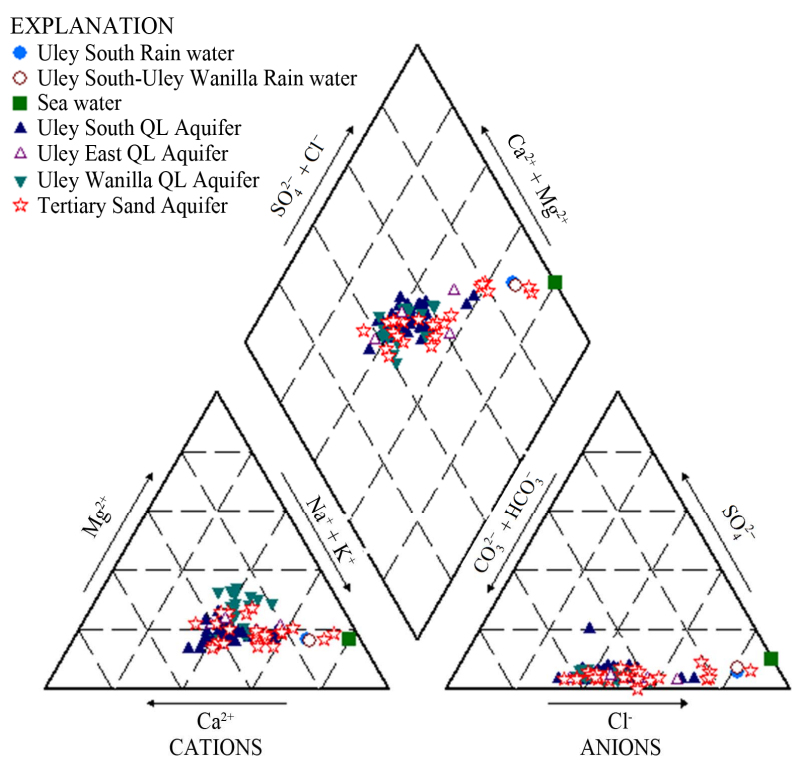

Figure 5. Piper diagram showing water types.

holes collect runoff containing organics; this provides sufficient $\mathrm{CO}_{2}$ for the following reactions to dissolve calcite.

The main mechanism for dissolution of calcite is as follows:

$$
\mathrm{CaCO}_{3}+\mathrm{CO}_{2}+\mathrm{H}_{2} \mathrm{O}=\mathrm{Ca}^{2+}+2 \mathrm{HCO}_{3}^{-}
$$

The above reaction includes the following steps:

$$
\begin{gathered}
\mathrm{CO}_{2}+\mathrm{H}_{2} \mathrm{O}=\mathrm{H}^{+}+\mathrm{HCO}_{3}^{-} \\
\mathrm{CaCO}_{3}+\mathrm{H}^{+}=\mathrm{Ca}^{2+}+\mathrm{HCO}_{3}^{-}
\end{gathered}
$$

\subsubsection{Na-Ca-Cl-HCO ${ }_{3} / \mathrm{Na}-\mathrm{Ca}-\mathrm{HCO}_{3}-\mathrm{Cl}(4)$}

$\mathrm{Na}-\mathrm{Ca}-\mathrm{HCO}_{3}-\mathrm{Cl}$ water types represent $\mathrm{Ca}-\mathrm{HCO}_{3}$ water affected by mixing with $\mathrm{Na}-\mathrm{Cl}$ waters or that has undergone cation exchange processes. The most common occurrence of such water is in the central basin (Figure 6), where high salinity waters originating from Big Swamp enter the QL aquifer. In addition another possible reason for the occurrence of this water type is cation exchanges, along with sea aerosol in the coastal zone.

\subsection{Influence on Coastal Salinity}

Seawater intrusion is generally identified through chemical analysis of groundwater. No single analysis definitively identifies seawater intrusion [27]; however by examining various analysis methods, it is evident when fresh groundwater mixes with seawater. According to HydroMetric WRI [27], at low chloride concentrations, it is often difficult to identify incipient seawater intrusion. This is due to the natural variation in fresh water chemistry at chloride concentrations below $1000 \mathrm{mg} / \mathrm{L}$.

Mixing trends between groundwater and seawater are 


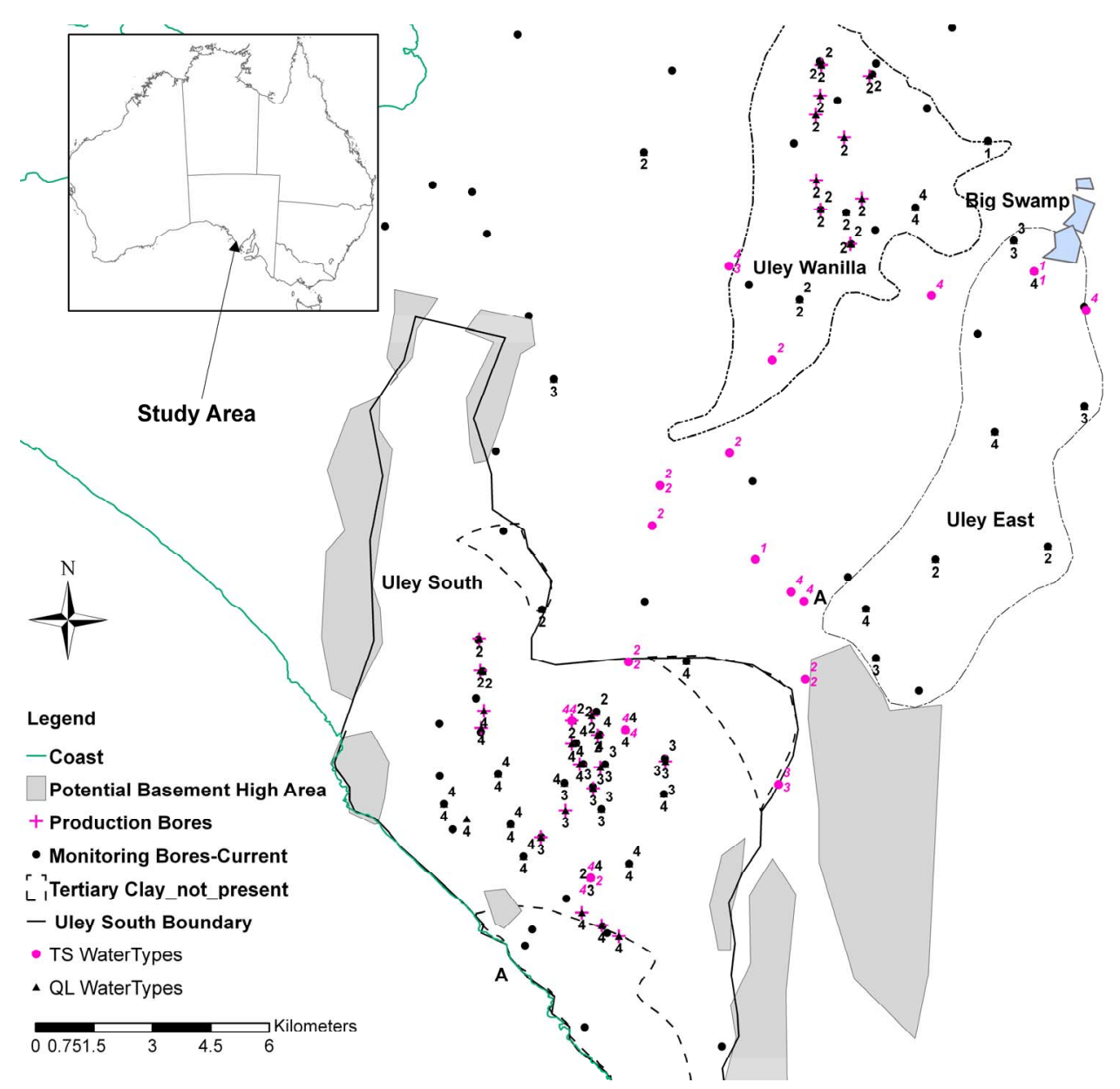

Figure 6. QL and TS aquifer water type distribution (1 = Na-Cl or Na-Ca-Cl; 2 = Na-Mg-Ca-Cl-HCO or a-Ca-Mg-HCO $_{3}-\mathrm{Cl}$ or Ca-Na-Mg-HCO ${ }_{3}-\mathrm{Cl} ; 3$ = Ca-Na-HCO ${ }_{3}-\mathrm{Cl}$ or Ca-Na-Cl-HCO ${ }_{3} ; 4=\mathrm{Na}-\mathrm{Ca}-\mathrm{Cl}-\mathrm{HCO}_{3}$ or $\left.\mathrm{Na}-\mathrm{Ca}-\mathrm{HCO}{ }_{3}-\mathrm{Cl}\right)$.

more easily defined when chloride concentrations exceed $1000 \mathrm{mg} / \mathrm{L}$, as is evident in Figure 7 where mixing increases with depth. As shown in Figure 7, groundwater mixing takes place in coastal aquifer monitoring wells from $\mathrm{Na}-\mathrm{Ca}-\mathrm{Cl}-\mathrm{HCO}_{3}$ to $\mathrm{Na}-\mathrm{Cl}$ water types at two different distances from the coast at the same elevation. On the northern side, TS groundwater is derived from downward leakage from the Uley Wanilla-Big Swamp system, which is approximately $22 \mathrm{~km}$ from the coastline. TS receives further direct recharge from areas where Tertiary Clay is absent.

Therefore, it is conceptualised that a large quantity of TS groundwater flows on the northern side with a higher hydraulic gradient $(0.00458)$. This makes the distance to the toe of the saline wedge in TS smaller, less than $500 \mathrm{~m}$ on the northern side. In contrast, the TS aquifer on the southern side receives leakage from the QL aquifer within Uley South basin. The extent of the TS is limited only to the Uley South boundary, which is on average approximately $5 \mathrm{~km}$ from the coast, yielding an average hydraulic gradient of 0.00117 . This results in comparatively small groundwater flows through TS along the southern side, creating a longer saline wedge for pressure balance at the same elevation. Distance to the toe of the saline wedge is about $900 \mathrm{~m}$ from the coastline on the southern side. In Uley South coastal aquifer monitoring wells, sea water is intercepted in Tertiary Sand aquifer in SLE069 at $-23 \mathrm{~m}$ AHD and in ULE205 at $-30 \mathrm{~m}$ AHD (Figure 7(b)) showing increasing salinity with depth. No QL aquifer coastal bores intercept saline waters indicating that the saline wedge in QL aquifer is less than 500 m.

\section{Conclusions}

We highlight the importance of integrating knowledge of hydrochemistry of groundwater sources into estimation of recharge and the potential for saline intrusion, both of which are essential components in assisting with effective management of groundwater resources. In particular, we analysed the groundwater chemistry from the Uley South coastal aquifer in South Australia, and examined the processes that control groundwater chemistry. The major outcome of this study is identification of two distinct groundwater sources due to geological controls and 


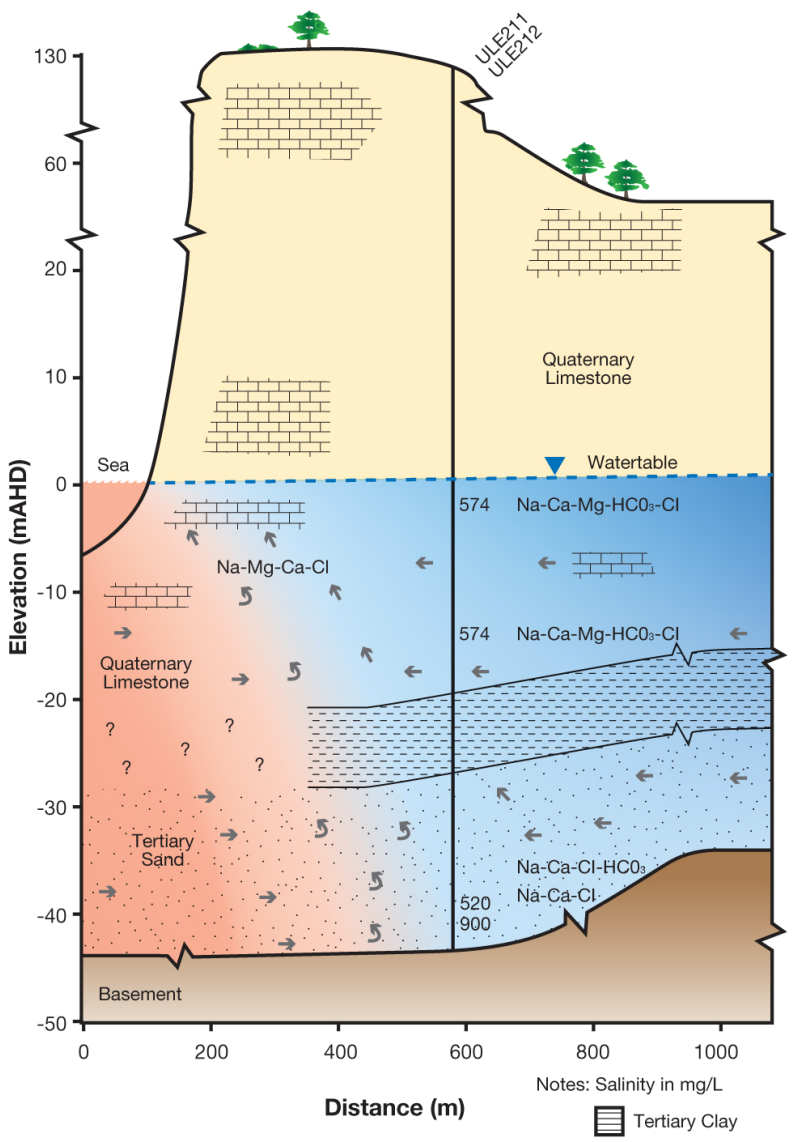

(a)

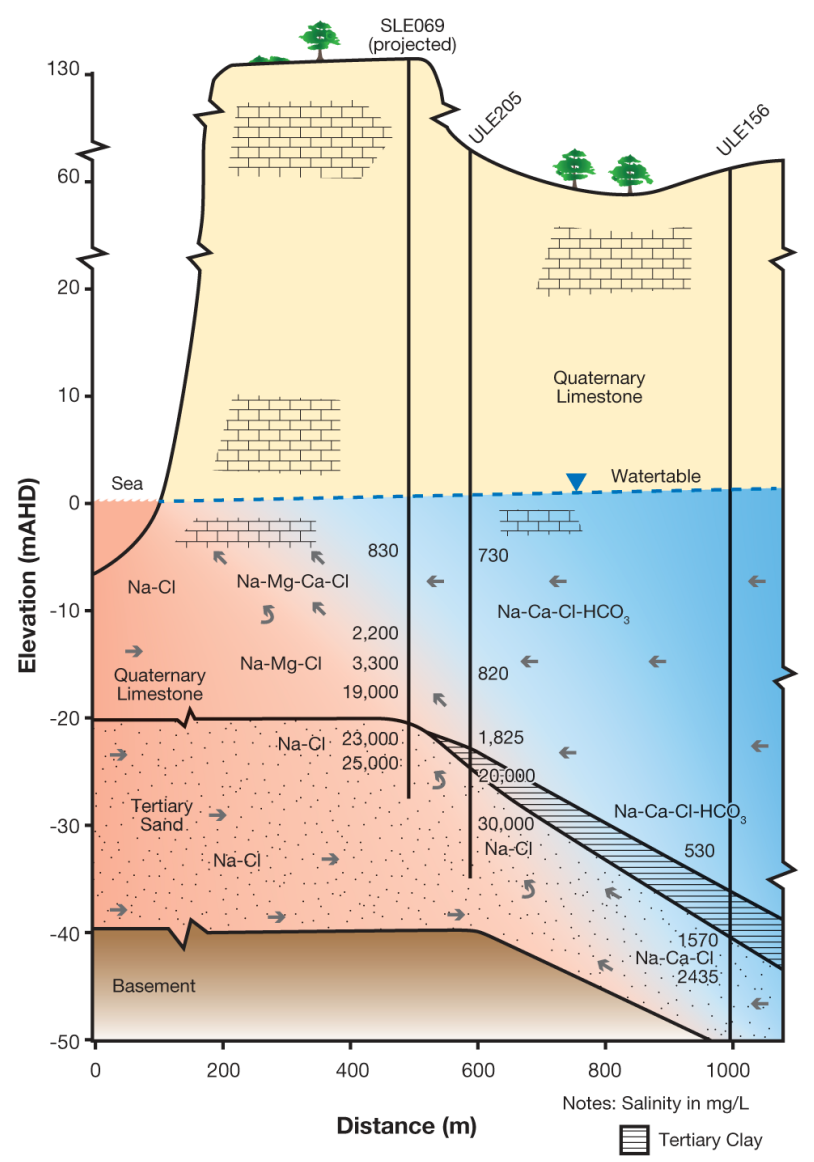

(b)

Figure 7. Uley South Saline Wedge. (a) Northern side; (b) Southern side.

their influence on groundwater chemistry. The geologic controls that led to these two distinct sources of different origin and age, were evidenced in the presence of two features, basement rock highs and absence of an aquitard.

Evaluation of hydrochemical data suggests that calcium carbonate dissolution, ion exchange processes and mixing with sea aerosols in the coastal zone are the main factors influencing groundwater chemistry. When the two groundwater sources with different ages and different chloride concentrations mix, results in unreliable recharge estimates are likely to result in using CMB and CFC methods. In addition, the subsurface basement rock high influences the currently observed seawater wedge. The toe of the saline wedge has been observed between $900 \mathrm{~m}$ and $500 \mathrm{~m}$ inland. Thus knowledge of geological control in the groundwater system, as well as the hydrogeochemical makeup of groundwater source(s), forms important parts of the characterisation of groundwater basin, ultimately contributing to effective management of the groundwater resources.

\section{Acknowledgements}

The editor and reviewers are thanked for evaluating this paper.

\section{REFERENCES}

[1] L. Lakshmanan, R. Kanan and M. Senthi Kumar, "Major Ion Chemistry and Identification of Hydrogeochemical Processes of Groundwater in a Part of Kancheepuram District, Tamil Nadu, India," Environmental Geosciences, Vol. 10, No. 4, 2003, pp. 157-166. http://dx.doi.org/10.1306/eg100403011

[2] M. Lorite-Herrera and R. Jiménez-Espinosa, "Impact of Agricultural Activity and Geologic Controls on Groundwater Quality of the Alluvial Aquifer of the Guadalquivir River (Province of Jaén, Spain): A Case Study," Environmental Geology, Vol. 54, No. 7, 2008, pp. 1391-1402. http://dx.doi.org/10.1007/s00254-007-0920-6

[3] R. M. Delinom, "Structural Geology Controls on Groundwater Flow: Lembang Fault Case Study, West Java, Indonesia," Hydrogeology Journal, Vol. 17, No. 4, 2009, pp 1011-1023. http://dx.doi.org/10.1007/s10040-009-0453-z

[4] G. Green, E. Watts, D. Alcoe, A. Costar, and L. Mortimer, "Groundwater Flow across Regional Scale Fault," Department for Water, South Australia, Technical Report DFW 2010/15, 2010.

[5] S. T. Finch, A. Mccoy and E. Melis, "Geologic Controls 
on Groundwater Flow in the Mimbres Basin, South Western New Mexico," New Mexico Geological Society Guide Book, 59th Field Conference, 2008, pp. 189-198.

[6] J. K. Mulwa, S. J. Garciri, J. O. Barongo, N. OpiyoAkech and G. K. Kianji, "Geological and Structural Control Influence on Groundwater Distribution and Flow in Ngong Area, Kenya," African Journal of Science and Technology, Science and Engineering Series, Vol. 6, No. 1, 2005, pp. 105-115.

[7] T. T. Eaton, M. P. Anderson and K. R. Bradbury, "Fracture Control of Ground Water Flow and Water Chemistry in a Rock Aquitard," Groundwater, Vol. 45, No. 5, 2007, pp. 601-615.

http://dx.doi.org/10.1111/j.1745-6584.2007.00335.x

[8] T. E. S. Odeh, M. Schirmer and G. Strauch, "Structural Control of Groundwater Flow Regimes and Groundwater Chemistry along the Lower Reaches of the Zerka River, West Jordan, Using Remote Sensing, GIS and Field Methods," Vol. 58, No. 8, 2009, pp. 1707-1810.

[9] V. F. Bensel, R. T. Van Balen and J. J. De Vries, "The Impact of Faults on the Hydrogeological Conditions in the Roer Valley Rift System: An overview," The Netherlands Journal of Geosciences/Geologie en Mijnbouw, Vol. 82, No. 1, 2003, pp. 41-54.

[10] J. Meeder, "Karst Control of the Biscayne Aquifer Groundwater Flow Patterns. The Biscayne and Other Eogenetic Karst Aquifers: Characterization, Modeling, and Management," Geological Society of America, Annual Meeting and Exposition, Paper 77-6, 2012.

[11] J. A. Cherry, B. L. Parker, K. R. Bradbury, T. T. Eaton, M. G. Gotkowitz, D. J. Hart and M. A. Borchardt, "Role of Aquitards in the Protection of Aquifers from Contamination: A State of the Science Report," AWWA Research Foundation, Denver, 2004.

[12] R. W. Segnit, "Final Report on the Uley Wanilla Fresh Water Basin, Eyre Peninsula," South Australian Department of Mines, 1942.

[13] R. K. Johns, "Geology and Mineral Resources of Southern Eyre Peninsula," Geological Survey of South Australia, Bulletin 37, 1961.

[14] W. Morton and T. M. Steel, "Eyre Peninsula Groundwater Study-Uley South Basin, Progress Report 1, Southern Eyre Peninsula," Mineral Resources Reviews, South Australia, 128, 1970, pp. 33-48.

[15] C. C. Wilson, "Geology of the Quaternary Bridgewater Formation of Southwest and Central South Australia," $\mathrm{PhD}$ Thesis, Flinders University of South Australia (unpublished), 1991.
[16] R. G. Shepherd, "Report on Underground Water Investigations-Sleaford Bay-Coffin Bay Area," Department of Mines (Unpublished Report), 1963.

[17] N. Harrington, D. Zulfic and D. Wohling, "Uley Basin Groundwater Modelling Project. Vol. 1: Project Overview and Conceptual Model Development," DWLBC Report 2006/01, Government of South Australia, 2006.

[18] N. Somaratne, "Hydrogeology of the Uley South Basin," SA Water Hydrogeological Research, SA Water/2013-1, 2013.

[19] S. L. Evans, "Estimating Long-Term Recharge to Thin, Unconfined Carbonate Aquifers Using Conventional and Environmental Isotopes Techniques: Eyre Peninsula, South Australia," Masters Thesis, Flinders University of South Australia (unpublished), 1997.

[20] C. M. Ordens, A. D. Werner, V. E. A. Post, J. L. Hutson, C. T. Simmons and B. M. Irvine, "Groundwater Recharge to a Sedimentary Aquifer in the Topographically Closed Uley South Basin, South Australia," Hydrogeology Journal, 2011.

[21] G. S. Weissmann, Y. Zhang, E. M. LaBolle and G. E. Fogg, "Dispersion of Groundwater Age in an Alluvial Aquifer System," Water Resources Research, Vol. 38, No. 10, 2002, p. 1198. http://dx.doi.org/10.1029/2001WR000907

[22] L. N. Plummer, E. Busenberg and L. F. Han, "Chapter 5: CFCs in Binary Mixtures of Young and Old Groundwater. Use of Chloroflurocarbons in Hydrology: A Guide Book," International Atomic Energy Agency, 2006.

[23] W. W. Wood and W. E. Sanford, "Chemical and Isotopic Methods for Quantifying Groundwater Recharge in a Regional Semi-Arid Environment," Ground Water, Vol. 33, No. 3, 1995, pp. 458-468.

http://dx.doi.org/10.1111/j.1745-6584.1995.tb00302.x

[24] W. W. Wood, "Use and Misuse of the Chloride Mass Balance Method in Estimating Groundwater Recharge," Groundwater, Vol. 37, No. 1, 1999. http://dx.doi.org/10.1111/j.1745-6584.1999.tb00949.x

[25] E. Custodio, "Hydrogeochemistry and Traces," In: E. Custodio and G. A. Brugeman, Eds., Groundwater Problems in Coastal Areas, Studies and Reports in Hydrology, Vol. 45, 1987, pp. 213-269.

[26] P. Heisig, "Groundwater Resources of the Clifton Park Area, Saratoga County, New York," US Geological Survey, Water Resources Investigation Report 01-4104, 2002.

[27] W. R. I. HydroMetrics, "Seawater Intrusion Analysis Report, Seaside Basin, Monterey County, California," 2011. 